Addaiyan Journal of Arts, Humanities and Social Sciences

(C) Addaiyan International Publishers

(An international Publisher of Research \& Academic Resources)

ISSN: 2581-8783 (Online)

Journal Homepage: https://aipublisher.org/projects/ajahss/

DOI: 10.36099/ajahss.3.11.8

\title{
EFL Learners' Use of Language Learning Strategies to Handle Language Anxiety
}

Syamsudin ${ }^{1}$, M. Jamal Abdul Nasir ${ }^{2}$

${ }^{1}$ State Islamic University Maulana Malik Ibrahim of Malang, Malang-Indonesia,

${ }^{2}$ Gajayana University of Malang, Malang-Indonesia,

Corresponding Author*

Ken N Falculan

Article History

Received: 11.11.2021

Accepted: 14.11.2021

Published: 22.11.2021

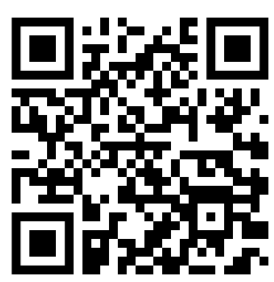

Abstract: This study is about the use of language learning strategies by the students of the English Letters department of one of the Islamic Universities in Malang to handle language anxiety to improve their speaking skills. This study aims at discussing the result of some observations and in-depth interviews to two EFL learners using language learning strategies to handle language anxiety to improve their speaking skills. This study applies a descriptive case study involving two EFL learners as the subject of the study. From the study, it is found that EFL learners might experience language anxiety due to several factors/ conditions. It is necessary for the EFL learners to be acquainted more with the use of language learning strategies to handle language anxieties so that they might improve their speaking skills.

Keywords: Language learning strategies, language anxiety, speaking skills.

\section{INTRODUCTION}

Speaking is one of the most important skills that EFL learners should learn in EFL learning. By mastering speaking, learners might be able to express their ideas well. However, it is not easy to master speaking skills. There are many learners who have learned speaking for some years still feel difficult to master this skill. There are several factors that might make learners feel difficult to master the speaking skill and one of them is due to language anxiety. The term "anxiety" is generally defined as a state of apprehension and fear resulting from predicting a threatening situation or event (Hilgard, Atkinson, \& Atkinson, 1971). Anxiety is a phenomenon characterized by a feeling of discomfort, nervousness, fear, and apprehension that is not associated to a specific situation or event (Krashen, 1985, Alrabai, 2014). Anxiety is related to learning a second or foreign language, it is known as second or foreign language anxiety. According to Horwitz (2001), language anxiety is different from a general feeling of anxiety. Foreign language anxiety is a distinct complex of self-perceptions, beliefs, feelings, and behaviors related to classroom language learning arising from the uniqueness of the language learning process. From this perspective, they claimed that language anxiety is unique due to the way it involves learners' self-concepts to communicate competently and to present themselves genuinely. There are several factors causing this kind of anxiety, as what has been divided by Horwitz \& Cope (1986). First, communication apprehension 
which arises from learners' inability, that they cannot adequately express mature thoughts and ideas. Second, fear of negative social evaluation, which arises from a learner's need to make a positive social impression on others. Third, test anxiety, and apprehension about academic evaluation. This anxious feeling is known as Foreign Language Anxiety (FLA). According to Macintyre and Gardner (1994), foreign language anxiety is the feeling of tension and apprehension specifically associated with second language contexts, including speaking, listening, and learning.

To handle language anxieties in learning to speak, EFL learners need to know more about language learning strategies. Oxford and Nyikos (1989, p.291) defined learning strategies as "operations used by learners to aid the acquisition, storage, and retrieval of information. O'Malley and Chamot (1990, p.2) stated that learning strategies are special methods of processing information that increase the understanding, learning, or retention of the information. According to Ehrman and Oxford (1990 p.312) strategies are conscious steps or behaviors used by language learners to improve the acquisition, storage, retention, memory, and use of new information. Oxford (1990) stated that learners' use of LLS might make learning become easier, faster, more enjoyable, more self-directed, more effective, and more transferable to new situations. There are some models of LLS and Oxford (1990) that developed language learning strategies into six categories such as memory, cognitive, compensation, metacognitive, affective, and social strategies. Thus, there are some models of language learning strategies, and using the right language learning strategies, EFL learners might be able to solve their language learning problems such as language anxiety to achieve their learning goals. In the process of learning speaking, using the right learning strategies might improve learners' speaking skills.

Related to language learning strategies and language anxiety, this study is going to discuss the use of language learning strategies to handle language anxiety in learning speaking. This study is focused on discussing the factors causing language anxiety experienced by EFL learners and the learning strategies that they use to handle language anxiety to improve their speaking skills. It covers the description of the research method, and the discussion of research findings related to some theories of language anxieties, language learning strategies, and language proficiency.

\section{Description of Research Method}

This study uses a descriptive qualitative case study design. Merriam (1988) said that a case study is a comprehensive investigation of one setting, or one single subject, a single depository of documents, or one particular event). In a qualitative investigation in education, the researcher depends on the research participants. The researcher gathers the data from the subjects in the form of words and he describes and analyzes these words based on themes (Creswell, 2002: 46). Bogdan and Biklen (1992) state that data are specific evidence that shapes the basis of analysis. It consists of all actions that people are doing, diaries, photographs, official documents, and newspaper articles. The strength of qualitative data is their richness and wholeness, with strong potential for revealing complexity, such data provide "thick descriptions" that are vivid nested to the real context, and truthful (Miles and Huberman, 1994). Data refer to all information needed and collected by the researcher as the basis to answer the research questions (Susanto, 2010). Thus, data is needed to answer the research questions. 
In this study, I have involved two EFL learners as the subjects of the study, subject $1 / \mathrm{S} 1$, and subject 2/S2. They are chosen as the subjects of the study because they are found to be very active in the speaking class discussion. The data would be in the form of verbal and non-verbal expressions expressed by the subjects. The data were collected through observations and in-depth interviews. In the observation, the researcher observed the subjects when they presented a presentation. During the subjects' presentation, the researcher tried to find out some expressions showing anxieties done by the subjects. Next, the researcher further asked the subjects about the factors that make them feel anxious. In addition, the researcher asked them about the language learning strategies that they employed to handle their feeling of anxieties. Then, I discuss the collected data related to some theories of language anxieties, language learning strategies, and language proficiency.

\section{Finding and Discussion}

From the analysis, it is found that subject 1/S1 experienced language anxieties during the presentation. It can be known when he could not express his ideas fluently. This feeling of language anxiety happened due to his lacks of vocabularies. He said: "I feel anxious in speaking when I felt I have little vocabs in my mind". Next, he also said that language anxieties might also happen when he practiced speaking English with somebody having better English than him. Besides, He might also feel anxious in the conversation when he was speaking with native speakers. He said: "I sometimes feel anxious when I was face to face with native speakers or someone who was better in English". He concluded that his feeling of anxiety might be caused by several factors such as being lacks of vocabularies, speaking in front of the audience and speaking to native speakers, or to someone having better English than him. He said: "my feeling of anxieties might be caused by some factors such as being lack of vocabularies, when I have to speak in front of the audience, and also when people who speak with me is having better English than me or when I have to speak with native speakers". This feeling of anxiety might further bring him to become speechless stuttering and tremor. He said: "This feeling of anxiety might bring me to feel speechless, stuttering and tremor". To handle those feeling of anxieties he has done several things such as trying to be relaxed, to control the emotion, to speak the important thing only and add more vocabularies. He said: "I handle this feeling by trying to relax, control my emotions, speak the important thing only and add more vocabulary".

An important point to be noted is that subject 1/S1 experienced language anxieties during the conversation. This feeling might make him feel difficult to speak fluently. It happened due to his limited vocabularies so that during the presentation he could not express his ideas fluently. Next, he experienced language anxiety when he had to speak in front of the audience, to speak to someone having better English than him or when he had to speak with a native speaker. This feeling of language anxiety might make him become speechless, stuttering and tremor. To handle this language anxiety he has applied several learning strategies such as trying to be relaxed, controlling his emotions, and also trying to increase his vocabularies.

Next, subject 2/S2 also experienced feeling anxious during his speaking practices. It happened when he has to speak in front of some or a lot of people. He said, "That feeling will there when I'm speaking in front of many people or few..". He also experienced language anxiety due to his lacks of vocabularies. 
He said: “...But, sometimes I feel anxious when I lack vocabulary..”. In addition, he experienced language anxieties when he had not mastered the material to be discussed well. He said, "...I feel anxious in some conditions, including speaking in front of many people about material that I have not fully mastered". Besides, he felt language anxiety when he could not pronounce the words correctly. He said, "I feel nervous because of lack of vocabulary and I don't know how to pronounce the word". For him, this feeling of anxiety is very disturbing to his appearance in front of the audience and might make him difficult to concentrate to the materials to be presented. He said: "The impact of feeling anxious is very disturbing to my appearance when speaking in front of many people. One of them is disturbing the concentration of the material to be delivered". To handle those feelings of anxieties he did some actions such as thinking positively, increasing vocabulary mastery, and having self-confidence. He said, "..I have to overcome anxiety when doing the speaking skill. There are several ways to deal with feeling anxiety, the first is thinking positively, the second is adding vocabulary, and the last is confident to myself'.

An important point to be noted is that subject 2/S2 experienced language anxieties during the conversation. This feeling might make him feel difficult to concentrate on presenting the materials fluently. It happened due to his limited vocabularies so that during the presentation he could not express his ideas fluently. Next, he experienced language anxiety when he had to speak in front of a few or lots of people. Next, he might also feel anxious when he could not pronounce words correctly. This feeling of language anxiety might make him to feel disturbed and difficult to concentrate in his presentation. To solve this problem he has applied several learning strategies such as thinking positively increasing vocabulary, and building self-confidence.

From the findings above, an important point to be noted is that both EFL learners experienced language anxiety when they were speaking. Their language anxiety were caused by some factors such as being lack of mastery of vocabularies, having little mastery of the topic to be presented or discussed, speaking in front of the audience, speaking to someone having better English than him, or when he had to speak with a native speaker or when they could not pronounce the word correctly. Related to factors causing learners' language anxiety, this study is in accordance to the study done by Fadlan (2020) stating that the students' feeling of anxiety in speaking was caused by some factors such as being afraid of making mistakes, being afraid of getting some questions, being afraid of the exam failure, being unable to find proper words to express, being lack of self-confidence, being lack of proficiency, being insufficient preparation and practice, having poor pronunciation, the students' perception about examiners or feeling inferior to others, having insufficient experience in presentation. In addition, This study is also in accordance to Zhang and Zhong (2012) stated that there are several possible causes for language anxiety such as learner-induced anxiety, Classroom-related Anxiety, Skill-specific Anxiety, and Societyimposed Anxiety. Learner-induced anxiety might be caused by learners' erroneous beliefs, unrealistic high standards, poor language abilities, self-perceived incompetence, inclined competitive nature, and dispositional fear of negative evaluation. Next, classroom-related Anxiety is related to some variables as instructors, peers, and classroom practices. Then, skill-specific Anxiety might be arisen during the language practice such as in speaking, reading, listening, and writing/ test-taking. Society-imposed Anxiety refers to language anxiety which is caused by the society that holds identity formation, cultural 
connotation, and parental intervention. Next, Woodrow (2006) stated that there is a difference between in-class and out-of-class anxiety. Speaking with the teachers and presenting the presentation in front of a class is the main factor to language anxiety in speaking classes. In addition, some conditions might become learners' reasons for language anxiety such as giving oral presentations, role-play in front of the class, contribution to formal discussions, answering teacher questions, and students' skills deficit or retrieval interference.

From the above discussion, it is found that there are several factors, internal and external factors, that might become the causes for learners' language anxiety in learning speaking such as speaking in front of the class, lack of vocabulary mastery, poor pronunciation, lack of the material mastery presented, oral presentation in front of the audience, lack of confidence, afraid of making mistakes, etc. All of those factors have made learners experience language anxiety. Thus, it might be concluded that in the process of learning to speak, some factors or conditions might become the causes of learners' language anxiety. It is in line to Horwitz and cope stating that language anxiety is more than a sum of its parts and define foreign language anxiety as 'a distinct complex of self-perceptions, beliefs, feelings, and behaviors related to classroom learning arising from the uniqueness of the language learning process' (Horwitz, Horwitz and Cope 1986; Horwitz 1986). Next, Tanveer (2007) stated that each factor or situation making the possibilities of showing their deficiencies and language weaknesses in front of others is possible to cause language anxiety for ESL/EFL learners. There are some conditions that might create language anxiety such as classroom interaction in the form of an open class forum, group participation or class presentation, or giving a short talk in any public event is likely to challenge their communicative abilities.

Next, language anxiety has caused EFL learners to have speaking problems during speaking practices such as feeling nervous, loosing concentration to deliver the topic, being speechless, trembling, stuttering, and finally difficult to speak. It is in line to Skehan (1989) stating that there is a connection between anxiety and self-perception for example self-confidence. MacIntyre and Gardner (1991) stated that most of the problems that students meet in the language learning process are caused by language anxiety that hinders the process of learning and the production of the target language. Anxiety has a negative influence on foreign language learning and many researchers have concluded that anxiety level is one of the most important criterion criteria predicting the success of a foreign language (Aida, 1994; Horwitz, 1986; Young, 1986). Feelings of anxiety are commonly experienced by Saudi learners in their English as a foreign language (EFL) classes. These feelings typically cause negative impacts on these learners' foreign language achievement (Alrabai, 2014).

To handle language anxiety becoming a part of speaking problems, both Subject 1/S1 and Subject 2/S2 have applied some learning strategies such as trying to be relaxed while speaking, controlling his emotions, having self-confidence, and also adding vocabularies. In this case, to handle their speaking problem in the form of language anxiety, both learners have applied some strategies, direct and indirect strategies, such as memory, cognitive, metacognitive, and affective strategies. This is in line to Oxford (1990) that classified learning strategies into direct and indirect strategies. Direct strategies cover memory, cognitive, and compensatory (or compensation) strategies. And indirect strategies cover metacognitive, affective, and social strategies. By applying those strategies learners might handle their speaking problems like anxiety to speak more fluently. This is in line to O'Malley \& Chamot (1990) 
stating that language learning strategies are generally defined as the tools that language learners consciously use to support their comprehension, learning, and recall of new information. Language Learning Strategies (LLS) which comprise the direct and indirect strategies are specific actions, behaviors, steps, or techniques that students often intentionally use to improve their progress in developing L2 skills as they can facilitate the internalization, storage, retrieval, or use of the new language (Oxford, 1993). They are tools for the self-directed involvement needed for developing communicative ability in learning a target language like ESL (Oxford, 1990). Nunan (1991) stated that to be able to speak well, learners should master some language elements such as grammar, vocabulary, intonation, pronunciation, stress, and the choice of language functions. In addition, the standard for the learners to speak well is reflected in the pronunciation elements such as sounds, speed pausing, stress, and intonation. Thus, using language learning strategies, help EFL learners might handle their speaking problems due to language anxiety caused by some factors/ conditions.

\section{Conclusion}

From the analysis above, it might be concluded that language anxiety can appear due to several factors/ conditions such as being lack of vocabulary mastery, having poor pronunciation, having little mastery of the topic presented or discussed, speaking in front of the audience, speaking to someone having better English, or when he had to speak with a native speaker. Language anxiety might bring speaking problems for EFL learners that might make them feel difficult to achieve proficiency in speaking. To handle language anxiety, it is urgent for EFL learners to know more language learning strategies. Using the right language learning strategies, in the process of learning speaking, learners might be able to handle their speaking problems due to language anxiety and improve their speaking skills.

\section{REFERENCES:}

1. Aida, Y. (1994). Examination of Horwitz, Horwitz, and Cope's Construct of Foreign Language Anxiety: The Case of Students of Japanese. The Modern Language Journal, Vol. 78 , issue 2.

2. Alrabai, F. (2014). A Model of Foreign Language Anxiety in the Saudi EFL Context. English Language Teaching, 7(7), 82-101.

3. Bogdan, R.C. \& Biklen, S.K. (1992). Qualitative Research for Education: An Introduction to Theory and Methods. Boston: Allyn and Bacon.

4. Creswell, J.W. (2007). Qualitative Inquiry and Research Design. London: SAGE Publications.

5. Fadlan, A. (2020). Factors Causing Language Anxiety of EFL Students in Classroom Presentation. Jurnal Sinestesia, Vol. 10, No. 1

6. Hilgard, E. R., Atkinson, R. C., \& Atkinson, R. L. (1971). Introduction to Psychology (5th ed.). New York: Harcourt.

7. Horwitz, E. K. (1986). Preliminary evidence for the reliability and validity of a foreignlanguage anxiety scale. Tesol Quarterly, 20(3), 559-562

8. Horwitz, E. K., Horwitz, M. B., and Cope, J. (1986). Foreign language classroom anxiety. The Modern Language Journal, 70(2), 125- 132. 
9. Krashen, S.(1985). The Input Hypothesis: Issues and Implications. New York: Longman.

10. MacIntyre, P. D., and Gardner, R. C. (1994). The subtle effects of language anxiety on cognitive processing in the second language. Language Learning, 44, 283-305.

11. Merriam, S.B. (1998). The Case Study Research in Education. San Francisco: Jossey-Bass.

12. Miles, M.B. and Huberman, A.M. 1984. Qualitative Data Analysis. California: SAGE Publication, Inc.

13. Nunan, D. (1991). Language Teaching Methodology. A Textbook for Teachers. New York: Prentice Hall International, Ltd.

14. O’Malley, J.M. \& Chamot, A.U. (1990). Learning strategies in second language acquisition. New York: Cambridge University Press.

15. Oxford, R.L. (1990). Language learning strategies: What Every teacher should know. Boston. Heinle and Heinle.

16. Skehan, P. (1989). Individual Differences in Second Language Learning. (1st. Ed.). London: Edward Arnold.

17. Susanto. (2010). Konsep Penelitian Tindakan Kelas dan Penerapannya. Surabaya: Lembaga Penerbitan FBS UNESA

18. Tanveer, M. (2007). Investigation of the factors that cause language anxiety for ESL/EFL learners in learning speaking skills and the influence it casts on communication in the target language. A Dissertation.

19. Woodrow, L. (2006). Anxiety and speaking English as a second language. RELC, 37(3), 308328.

20. Zhang, R. and Zhong, J. (2012). The Hindrance of Doubt: Causes of Language Anxiety. International Journal of English Linguistics, Vol. 2, No. 3; June 2012. 